\title{
Pressure induced phase transition in $\mathrm{Pb}_{6} \mathrm{Bi}_{2} \mathrm{~S}_{9}$
}

\author{
L. A. Olsen ${ }^{\mathrm{a}, *}$, K. Friese ${ }^{\mathrm{b}}$, E. Makovicky ${ }^{\mathrm{a}}$, T. Balić-Žunić ${ }^{\mathrm{a}}$, W. Morgenroth ${ }^{\mathrm{c}}$, A. Grzechnik $^{\mathrm{b}}$ \\ a Department of Geography and Geology, University of Copenhagen, Copenhagen, Denmark \\ b Departamento de Física de la Materia Condensada, Universidad del País Vasco, Bilbao, Spain \\ c Institut für Geowissenschaften, FE Mineralogie, Abt. Kristallographie, Universität Frankfurt, \\ Germany \\ * Corresponding author: lao@geo.ku.dk
}

\begin{abstract}
The crystal structure of $\mathrm{Pb}_{6} \mathrm{Bi}_{2} \mathrm{~S}_{9}$ is investigated at pressures between 0 and $5.6 \mathrm{GPa}$ with $\mathrm{X}$-ray diffraction on single-crystals. The pressure is applied using diamond anvil cells. Heyrovskyite (Bbmm, $a=13.719(4) \AA, b=31.393(9) \AA, c=4.1319(10) \AA, \mathrm{Z}=4)$ is the stable phase of $\mathrm{Pb}_{6} \mathrm{Bi}_{2} \mathrm{~S}_{9}$ at ambient conditions and is built from distorted moduli of PbS-archetype structure with a low stereochemical activity of the $\mathrm{Pb}^{2+}$ and $\mathrm{Bi}^{3+}$ lone electron pairs. Heyrovskyite is stable until at least 3.9 $\mathrm{GPa}$ and a first order phase transition occurs between 3.9 and $4.8 \mathrm{GPa}$. A single-crystal is retained after the reversible phase transition despite an anisotropic contraction of the unit-cell and a volume decrease of $4.2 \%$. The crystal structure of the high pressure phase, $\beta-\mathrm{Pb}_{6} \mathrm{Bi}_{2} \mathrm{~S}_{9}$, is solved in ${\text { Pna }{ }_{1}(a=25.302(7) \AA,}(a=30.819(9) \AA, c=4.0640(13) \AA, Z=8)$ from synchrotron data at 5.06 $\mathrm{GPa}$. This structure consists of two types of moduli with SnS/TII-archetype structure in which the $\mathrm{Pb}$ and $\mathrm{Bi}$ lone pairs are strongly expressed. The mechanism of the phase transition is described in detail and the results are compared to the closely related phase transition in $\mathrm{Pb}_{3} \mathrm{Bi}_{2} \mathrm{~S}_{6}$ (lillianite).
\end{abstract}

\section{Keywords}

heyrovskyite; sulfosalt; high pressure; lone electron pair; equation of state

\section{Introduction}

Heyrovskyite, $\mathrm{Pb}_{6} \mathrm{Bi}_{2} \mathrm{~S}_{9}$, was synthesized as a part of work on the $\mathrm{PbS}-\mathrm{Bi}_{2} \mathrm{~S}_{3}$ system by Otto \& Strunz (1968) who also suggested a schematic crystal structure for the compound. Naturally occuring mineral was later described by Klomínský et al. (1971) and the suggested structure was confirmed and refined by Takéuchi and Takagi (1974). The crystal structure is orthorhombic Bbmm $(a \approx 13.7 \AA, b \approx 31.4 \AA, c \approx 4.1 \AA, \mathrm{Z}=4)$ and is built from distorted moduli of PbS-archetype (Fig. 1). The moduli are cut parallel to $(311)_{\mathrm{PbS}}$ and combined by mirror planes parallel to (010) of heyrovskyite (Makovicky and Karup-Møller 1977). The width of the moduli can be evaluated by counting the number of $\mathrm{PbS}$ octahedra running across each slab parallel to [011 $]_{\mathrm{PbS}}$. Heyrovskyite is a member of the lillianite homologous series, which is based on various thicknesses of the above defined slabs. Each homologue type is symbolized as ${ }^{N} L\left(N=\right.$ number of octahedra) or ${ }^{N 1, N 2} L$ when there are two slabs of distinct thicknesses. Heyrovskyite is the ${ }^{7} L$ member of the homologous series, whereas lillianite, $\mathrm{Pb}_{3} \mathrm{Bi}_{2} \mathrm{~S}_{6}$, is the ${ }^{4} L$ member (Makovicky and Karup-Møller 1977).

This article reports on a high pressure X-ray diffraction study on synthetic heyrovskyite. It follows a series of related studies on sulfosalts and sulfides of metalloids (Lundegaard et al. 2003, 2005, Olsen et al. 2007, 2008). These compounds contain elements like $\mathrm{Pb}, \mathrm{Bi}$ and $\mathrm{Sb}$ which often have distorted coordination environments due to the stereochemical activity of lone electron pairs. The distortion decreases at increasing pressure for most of the studied compounds. However, in 
lillianite, $\mathrm{Pb}_{3} \mathrm{Bi}_{2} \mathrm{~S}_{6}$, a first order phase transition which increases the stereochemical activity of the lone pairs is observed between 4 and $5 \mathrm{GPa}$ (Olsen et al. 2008). The crystal structures of lillianite and heyrovskyite are closely related and one of the aims of the present study was to investigate whether this relation is reflected in the high pressure behaviour of heyrovskyite.

\section{Experimental}

X-ray diffraction intensities from a synthetic single-crystal of heyrovskyite $\left(48\right.$ x 15 x $98 \mu \mathrm{m}^{3}$, crystal 1), were collected at ambient conditions using a CCD-equipped Bruker AXS four-circle diffractometer with MoKa radiation. The process for synthesizing the crystals is described by Elcoro et al. (2008). Software from Bruker AXS (SMART, SAINT+) was used for data integration and empirical absorption correction was performed with the SADABS-program. A second synthetic single-crystal of $\mathrm{Pb}_{6} \mathrm{Bi}_{2} \mathrm{~S}_{9}\left(43 \times 15 \times 100 \mu \mathrm{m}^{3}\right.$, crystal 2) was mounted in a Boehler-Almax type diamond anvil cell (Boehler 2006) (with diamond culets of $600 \mu \mathrm{m}$ ) together with a ruby chip for pressure calibration (Mao et al. 1986) and a methanol:ethanol $=4: 1$ mixture acting as a hydrostatic pressure medium. A series of X-ray intensity measurements at 1.68, 2.95, 3.92, 4.84, and 5.57 GPa were carried out on a STOE diffractometer IPDS-2T with MoKa radiation. STOE software (STOE \& $\mathrm{Cie} \mathrm{GmbH}$ ) was used to integrate high pressure data and correct for sample absorption effects via face-indexing. Data correction for the diamond anvil cell was performed with Absorb (Angel 2004). Although the data sets measured at 4.84 and $5.57 \mathrm{GPa}$ in the laboratory could well be used to determine the lattice parameters, they did not contain enough information about the reciprocal space (due to a relatively low energy of $\mathrm{MoK \alpha}$ radiation of the laboratory diffractometer IPDS-2T) to determine the crystal structure. For this reason, Crystal 1 was mounted in a ETH-type diamondbacked diamond anvil cell together with a quartz crystal for pressure calibration (Angel et al. 1997) and methanol:ethanol:water $=16: 3: 1$ as hydrostatic pressure medium. X-ray diffraction intensities at a pressure of $5.06 \mathrm{GPa}$ were collected at the beamline D3 in HASYLAB (Hamburg, Germany) at a wavelength of $0.4 \AA$. The vertical and horizontal slits of the collimator were closed to $0.4 \mathrm{~mm}$ each and the data were collected on a MARCCD-165 detector. The XDS program package (Kabsch 1993) was used to integrate the data. As the absorption corrections both for the crystal shape and the diamonds improved neither the internal agreement factors nor the final agreement factors of the refinement, we abstained of applying any correction for absorption effects. SIR97 (Altomare et al. 1999) was used for structure solution of the high pressure phase. All crystal structure refinements were performed with JANA2006 (Petrríček et al. 2006). The experimental data for crystal 1 are summarized in Table 1 and the unit-cell parameters of crystal 2 are listed in Table 2.

\section{Evolution of unit-cell parameters}

The two heyrovskyite crystals were measured on different X-ray diffractometers and at various pressures. The lengths of the unit-cell axes are plotted as a function of pressure in Fig. 2. The compression of the unit-cell is continuous between 0 and $3.92 \mathrm{GPa}$ and can be described using a Birch-Murnaghan Equation of State (B-M EoS) (Birch 1947). The unit-cell volumes were fitted to the B-M EoS using EoSFit5.2 (Angel 2000) and the data points were weighted with estimated standard deviations of volume and pressure. Due to the limited interval of pressure and the small number of data points we constrained the EoS to $2^{\text {nd }}$ order. The $2^{\text {nd }}$ order EoS implies a $K^{\prime}$ of 4 which is assumed to be a reasonable constraint for heyrovskyite as the closely related lillianite structure has a $K^{\prime}$ of 4.0(1.3) (Olsen et al. 2008). The fit of the data points from 0 to $3.92 \mathrm{GPa}$ yields a zero pressure volume $V_{0}=1780.2(7) \AA^{3}$ and bulk modulus $K_{0}=51.3(5) \mathrm{GPa}$ for heyrovskyite. The fit is satisfactory with deviations in observed and calculated pressure being less than $0.03 \mathrm{GPa}$. 
The close relationship between the crystal structures of heyrovskyite and lillianite $\left(K_{0}=48.4(1.7)\right.$ $\mathrm{GPa})$ is reflected in very similar bulk moduli.

A first order phase transition is observed between 3.92 and $4.84 \mathrm{GPa}$ where heyrovskyite transforms into $\beta-\mathrm{Pb}_{6} \mathrm{Bi}_{2} \mathrm{~S}_{9}$. The transition is clearly expressed by the appearance of a number of new reflections at the reciprocal lattice points $(h / 2 k l)$ of heyrovskyite, accompanied by the change from a $B$-centred to a primitive lattice. The lengths of the $b$ and $c$-axes increase slightly across the phase transition (Fig. 2), whereas the $a$-axis/2 in $\beta-\mathrm{Pb}_{6} \mathrm{Bi}_{2} \mathrm{~S}_{9}$ at $4.84 \mathrm{GPa}$ is $5.3 \%$ shorter than the $a$ axis in heyrovskyite at $3.92 \mathrm{GPa}$. The overall result of the phase transition is a contraction of the volume by $4.2 \%$.

The phase transition in $\mathrm{Pb}_{6} \mathrm{Bi}_{2} \mathrm{~S}_{9}$ has several points of similarity to the first order phase transition in $\mathrm{Pb}_{3} \mathrm{Bi}_{2} \mathrm{~S}_{6}$. Both transitions are observed between 4 and $5 \mathrm{GPa}$ and are accompanied by a volume decrease of approximately $4 \%$. The crystals still diffract as single-crystals after the phase transition in spite of the significant and anisotropic change in unit-cell parameters and the room pressure phases are re-established after the release of pressure.

The transition in $\mathrm{Pb}_{3} \mathrm{Bi}_{2} \mathrm{~S}_{6}$ (lillianite) transforms the crystal structure from space group Bbmm at low pressure to Pbnm at high pressure. For heyrovskyite, the systematic extinctions indicate Pnam and $P n a 2_{1}$ as possible space groups for $\beta-\mathrm{Pb}_{6} \mathrm{Bi}_{2} \mathrm{~S}_{9}$ after the transformation.

\section{Crystal structure of heyrovskyite}

The crystal structure of heyrovskyite has five distinct cation sites in the unit-cell. The $M 1$ site at the plane of the unit-cell twinning is a bi-capped trigonal prism and the four sites in the PbS-like slab have octahedral or quasi-octahedral coordinations. Refined atomic coordinates for synthetic Ag-free heyrovskyite of the present study are given in Table 3. Bond lengths from the refinement are listed in Table 4 along with reported bond lengths of $\mathrm{Ag}$-poor $\left(\mathrm{Pb}_{5.4} \mathrm{Ag}_{0.4} \mathrm{Bi}_{2.2} \mathrm{~S}_{9}\right.$, Takéuchi and Takagi 1974) and $\mathrm{Ag}$-rich $\left(\mathrm{Pb}_{3.36} \mathrm{Ag}_{1.32} \mathrm{Bi}_{3.32} \mathrm{~S}_{9}\right.$, Makovicky et al. 1991) heyrovskyite. The differences in bond lengths are small between the two former structures and considerably larger between Ag-free and Ag-rich heyrovskyite. Because of the similar number of electrons, $\mathrm{Pb}^{2+}$ and $\mathrm{Bi}^{+3}$ are indistinguishable by means of conventional X-ray diffraction techniques. The site occupancy can be deduced using bond lengths and geometrical characteristics of the coordination polyhedra. The $M 1$, $M 2$ and $M 3$ sites in Ag-poor heyrovskyite are taken as pure Pb-sites and M4 and M5 are assumed to have a statistical distribution of $\mathrm{Pb}$ and $\mathrm{Bi}$ (Takéuchi and Takagi 1974). $M 1$ is also taken as a pure $\mathrm{Pb}$-site in Ag-rich heyrovskyite, whereas $\mathrm{Bi}$ partially replaces $\mathrm{Pb}$ at the $M 2$ and $M 3$ sites. $M 5$ is assumed to be a pure Bi-site and M4 has mixed occupancy of $\mathrm{Ag}$ and Bi (Makovicky et al. 1991).

Looking at Ag-free heyrovskyite, the long bonds and large volume of $M 1$ are clear characteristics of a site occupied by $\mathrm{Pb}$. To establish the occupation of the octahedral sites bond-pairs are plotted in a xy-diagram (Berlepsch et al. 2001a) onto element specific bond-length hyperbola (Fig. 3). The in plane bond-pair refers to the two types of bonds which lie in the plane defined by the cation and four coordinating sulfurs of the octahedron, e.g. M4-S1 and M4-S4. Out-of-plane is the bond pair which lies approximately on a line perpendicular to this plane, e.g. M4-S2 and M4-S3. The M2 site plots between the two hyperbolas and this suggests a mixed occupancy of $\mathrm{Pb}$ and $\mathrm{Bi}$. The points of M3 lie close to the $\mathrm{Pb}$ hyperbola and indicate a pure $\mathrm{Pb}$-site. 
Determination of occupancy of $M 4$ and $M 5$ is more ambiguous. The plot of the out-of-plane bondpairs of M4 and M5 suggests that these sites are occupied mainly by Bi. A majority of Bi at the M4 and M5 sites is not possible, however, as it would violate the stoichiometry of heyrovskyite. The in plane bond-pairs plot between the two hyperbolas and close to the $\mathrm{x}=\mathrm{y}$ line and thus suggest a mixed occupancy of $\mathrm{Pb}$ and $\mathrm{Bi}$. Despite the mixed occupancy the out-of-plane bond-pairs can be ruled by the $\mathrm{Bi}$ component with a strong stereochemical activity of the lone electron pair. As realized by Berlepsch et al. (2001b) the situation of in plane bond-pairs plotting close to the $\mathrm{x}=\mathrm{y}$ line is not unusual in sulfosalts. Besides the effect of mixing, it might be caused by a split or socalled "flipping" position of the cation. For these two sites, the lengths of the bond-pairs might be an average of a long and a short bond. This idea is supported by the thermal ellipsoid of $M 4$ which is slightly elongated along the $a$-axis, whereas the thermal ellipsoid of $M 5$ shows no sign of elongation. Based on the above we take $M 1$ and $M 3$ as pure $\mathrm{Pb}$-sites and assume a mixed occupation of $\mathrm{Pb}$ and $\mathrm{Bi}$ at $M 2, M 4$, and $M 5$.

The stereochemical activity of a lone electron pair can be quantified by the cation eccentricity which measures the displacement of the cation relative to the centroid of the coordination polyhedron (Balić-Žunić and Makovicky 1996). The cation eccentricities of $M 1$ (CN [8]), M3, M4, and $M 5$ are $0.036,0,0.068,0.199$, and 0.228 , respectively. The $M 2$ site has eccentricity equal to 0 as it is placed at a centre of symmetry. The cation is not displaced from the centroid, but the polyhedron deviates from ideal octahedral symmetry by having four bonds of 2.922(7) $\AA$ and two bonds of 2.951(9) $\AA$. This type of coordination is not found in the even homologues of the lillianite series (like ${ }^{4} L$ ), where all cations have eccentricities above 0 . The cation eccentricities and the variation in bond lengths show that the deviations from ideal octahedral symmetry in heyrovskyite are small for the $M 2$ and $M 3$ sites in the central zone of the slab and markedly larger for the $M 4$ and M5 sites at the margins of the slab.

Like in lillianite the lone electron pairs in heyrovskyite cluster together in the structure in so-called

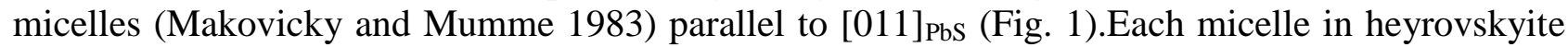
hosts three lone pairs, those of $M 3, M 4$, and $M 5$, and is thus smaller than the micelles in lillianite in which four lone pairs are hosted.

The detailed evolution of the crystal structure of heyrovskyite between 0 and $3.92 \mathrm{GPa}$ could unfortunately not be extracted from the experiments. The crystals have the shape of thin plates with the shortest dimension being along the $b$-axis. The diamond anvil cell reduces the resolution along the reciprocal $b^{*}$-axis considerably and the range of $k$ was cut down to $-12<k<13$. The structure could be refined to an $R$ value of less than $5 \%$ but, due to the limited completeness of the data set, the $R$-value was insensitive to movements of atoms along the $\sim 31 \AA$ long $b$-axis. This results in a set of crystal structure determinations with unreliable $y$ coordinates, which we choose not to report. However, they allow us to conclude that a practically undistorted crystal structure of heyrovskyite is retained until $3.92 \mathrm{GPa}$.

\section{Crystal structure of $\beta-\mathrm{Pb}_{6} \mathrm{Bi}_{2} \mathrm{~S}_{9}$}

The crystal structure of $\beta-\mathrm{Pb}_{6} \mathrm{Bi}_{2} \mathrm{~S}_{9}$ at $5.06 \mathrm{GPa}$ has been solved and refined to $R(\mathrm{obs})$ factors of 8.17\% and 9.09\% in Pna ${ }_{1}$ and Pnam (both $a=25.302(7) \AA, b=30.819(9) \AA, c=4.0640(13) \AA, Z$ $=8$ ), respectively. Pnam can be rejected as the right space group at the $0.5 \%$ significance level according to Hamilton's R-factor ratio test (Hamilton 1965). The results of the refinement in Pna $2_{1}$ 
are given in Tables 5 and 6 and the crystal structure is shown in Fig. 4. With the knowledge of the space group of the high pressure phase we also performed a Hamilton test on heyrovskyite to check the existence of the (001) mirror plane. The crystal structure was refined in Bbmm and Bbm2 and the test again rejected the former as the correct space group even at $0.5 \%$ significance level. However, while in the high pressure phase the displacements of the atoms from the mirror plane are significant, the same is not true for the ambient pressure phase where the displacements are considerably smaller than the standard deviations of the atomic coordinates. Therefore, the centrosymmetric space group was kept for the ambient pressure data.

The atoms in $\beta-\mathrm{Pb}_{6} \mathrm{Bi}_{2} \mathrm{~S}_{9}$ are named according to their connection to heyrovskyite with a subsequent letter to distinguish between atoms which are no longer symmetry equivalents. A detailed description of the phase transition is given below. The crystal structure of $\beta-\mathrm{Pb}_{6} \mathrm{Bi}_{2} \mathrm{~S}_{9}$ has 16 distinct cation sites. The main part of the coordination polyhedra around these sites can be recognized as lying-down mono-capped trigonal prisms when looking along [001]. The only exceptions are the standing trigonal prisms of $M 1 a, M 1 b$, and $M 4 c$, of which the former is mono-capped and the two latter are bi-capped.

The crystal structure of $\beta-\mathrm{Pb}_{6} \mathrm{Bi}_{2} \mathrm{~S}_{9}$ can be described as a rod-based layer structure. The layer (or slab) consists of two types of rods which are interconnected. Rod type 1 (dotted in Fig. 5) has SnSarchetype structure and is infinite parallel to $[010]_{\mathrm{SnS}}$. The rod can be characterised by its width $(N)$ and thickness $\left(N^{\prime}\right)$ according to the nomenclature of rod-based structures (Makovicky 1993). $N$ refers to the number of complete cation polyhedra along the tightly bonded double-layer running parallel to [001] $]_{\mathrm{SnS}}$ (approximately parallel to [100] for rod type 1 in $\beta-\mathrm{Pb}_{6} \mathrm{Bi}_{2} \mathrm{~S}_{9}$ ) and $N$ is the number of atom planes along [100] $]_{\mathrm{SnS}}$ (approximately parallel to [010] in $\beta-\mathrm{Pb}_{6} \mathrm{Bi}_{2} \mathrm{~S}_{9}$ ). Rod type 1 has a central part with $N=3$ and $N^{\prime}=4$. The thickness of the rod is extended on each side with an additional $N=1$ double-layer in faint resemblance to rods in the kobellite homologous series (Makovicky 1993). Rod type 2 (striped in Fig. 5) can also be described as SnS archetype structure infinite parallel to $[010]_{\mathrm{SnS}}$, however it approaches TII archetype structure with the coordinations $M S_{5+2}$. Rod type 2 has $N=3$ and $N^{\prime}=6$ with the surface being reduced to $N=2$. The two types of rods are hinged together along a zig-zag surface of S-atoms, so the tightly bonded double-layer of one type of rod meets the loosely bonded interspace of the other type of rod.

The wavy surface of each layer alternates between pseudotetragonal $(\mathrm{Q})$ and pseudohexagonal $(\mathrm{H})$ motifs of cations and anions; where a $\mathrm{Q}$ surface is a motif of sulfur and metal atoms and a $\mathrm{H}$ surface displays only sulfur atoms. The adjacent layers are fitted together so that rod type 1 opposes rod type 2 and a Q motif faces an H motif. This type of construction is widespread in the group of rodbased sulfosalts (Makovicky 1993).

All cations within the SnS/TII layers are coordinated by mono-capped trigonal prisms and have strongly expressed lone electron pairs. The cation is situated close to the capped face of the prism with short to intermediate bonds on one side and markedly longer bonds on the opposite side. The cation eccentricity for these sites falls in the range 0.41-0.57. The mono-capped prisms are stacked as face-sharing polyhedra parallel to [001]. This means that the cation-cation distance across the micelle in many cases is shorter than the longest $\mathrm{M}-\mathrm{S}$ distance in the polyhedron. The mono-capped trigonal prisms of $\mathrm{M} 4 \mathrm{a}$ and M5c are situated at the edge of the layer and the face-sharing polyhedron across the interspace is replaced by an edge-sharing standing trigonal prism. This 
results in cation eccentricities of 0.29 and 0.12 for M4a and M5c, respectively. The standing prisms of M1a, M1b and M4c make up the remaining part of the border of the layer and these sites have cation eccentricities in the range from 0.30 to 0.35 .

\section{Phase transition}

The phase transition from lillianite to $\beta-\mathrm{Pb}_{3} \mathrm{Bi}_{2} \mathrm{~S}_{6}$ can be described by splitting the $\mathrm{PbS}$-like slabs of the low pressure phase into double-layered rods parallel to [011 $]_{\mathrm{Pbs}}$. These rods are rotated as rigid bodies around their central axes parallel to the crystallographic $c$-axis in the process of the phase transition (Olsen et al. 2008). A similar approach can be used to describe the phase transition from heyrovskyite to $\beta-\mathrm{Pb}_{6} \mathrm{Bi}_{2} \mathrm{~S}_{9}$ and to subsequently compare the two observed pressure induced phase transitions in the lillianite homologous series.

The slabs of heyrovskyite can be split into a number of double-layered rods (hereafter called $s u b$ rods) which are retained across the phase transition and constitute the tightly bonded double-layers of the high pressure phase (Fig. 6). Going from heyrovskyite to $\beta-\mathrm{Pb}_{6} \mathrm{Bi}_{2} \mathrm{~S}_{9}$, the sub-rods are rotated as rigid bodies around their central axes parallel to [001]. The sub-rods which after the phase transition are a part of rod type 1 are rotated by approximately $16^{\circ}$ and increase the inclination angle of their longest diameter to the $b$-axis getting almost perpendicular to it. The sub-rods of rod type 2 are rotated in the opposite sense by approximately $19^{\circ}$. This means that the internal $[001]_{\mathrm{SnS}}$ directions of the two joined rods in $\beta-\mathrm{Pb}_{6} \mathrm{Bi}_{2} \mathrm{~S}_{9}$ are inclined by $35^{\circ}$ with respect to one another. The rotation is connected with a relative sliding of adjacent sub-rods. The relative movement between two parallel sub-rods corresponds approximately to one half of an octahedron or the sliding component $\left[\begin{array}{lll}0 & 1 / 2 & 1 / 2\end{array}\right]_{\mathrm{PbS}}$. The consequence is a migration of bonds between sub-rods, which can be seen by comparison of Fig. 1 and Fig. 4. Bonds are also broken and established across the (010) mirror plane of heyrovskyite which is transformed to a glide plane in the high pressure phase.

The structure in Fig. 6a presents only one out of four fully equivalent ways the sub-rods in heyrovskyite can be placed. The four different placements are related by a shift of $x=1 / 2$ of the heyrovskyite cell. The fact that a single-crystal is retained after the phase transition implies that once the transition takes place in one part of the crystal the sequence is determined for the rest of the structure and no twin domains appear.

Having established the process of the phase transition we would like to draw the attention to the M5a-S1c bond of $\beta-\mathrm{Pb}_{6} \mathrm{Bi}_{2} \mathrm{~S}_{9}$. This bond has a length of $2.35 \AA$ which is notably short compared to the other bonds of the structure. The bond is a part of rod type 1 and is found at the end of one of the rigid sub-rods which are rotated in the process for the phase transition. The bond is thus retained from the low pressure structure in which it is situated at the edge of the slab and also forms the shortest bond (M5-S1) with a length of $2.70 \AA$. It is remarkable that a similar situation is found in the case of $\mathrm{Pb}_{3} \mathrm{Bi}_{2} \mathrm{~S}_{6}$ (Olsen et al. 2008). The M1-S3 bond at the edge of the slab in lillianite has a length of $2.71 \AA$ at room pressure and is decreased to $2.63 \AA$ at $3.73 \mathrm{GPa}$ where it is the markedly shortest bond of the structure. The bond is retained in the high pressure structure, $\beta-\mathrm{Pb}_{3} \mathrm{Bi}_{2} \mathrm{~S}_{6}$, as it is rotated as the outermost bond of a rigid unit. With a length of $2.43 \AA$ at $5.27 \mathrm{GPa}$ it also forms the shortest bond of the high pressure phase. The special feature of the shortest bond becoming even shorter in the process of the pressure induced phase transition is thus common for the two studied members of the lillianite homologous series. 
The phase transition from heyrovskyite to $\beta-\mathrm{Pb}_{6} \mathrm{Bi}_{2} \mathrm{~S}_{9}$ is described above in terms of one to three octahedra wide rods which are rotated by $16-19^{\circ}$. The phase transition from lillianite to $\beta-\mathrm{Pb}_{3} \mathrm{Bi}_{2} \mathrm{~S}_{6}$ is a rotation of just one type of rod which is five octahedra wide and extends across the whole PbSlike slab of the low pressure phase. The rod is rotated by $5^{\circ}$ in a sense which reduces the inclination angle of its longest diameter to the $b$-axis and results in a SnS-type like slab. The phase transitions in $\mathrm{Pb}_{6} \mathrm{Bi}_{2} \mathrm{~S}_{9}$ and $\mathrm{Pb}_{3} \mathrm{Bi}_{2} \mathrm{~S}_{6}$ are based on the same mechanisms which transform modules of PbS-type into modules of SnS/TII-type. The transitions imply a collective migration of chemical bonds and some of the lone electron pairs are transferred to the opposite side of the atomic nuclei. The lone pairs have a weak stereochemical activity in the octahedra of the PbS-like slab and "pop out" with a strong stereochemical activity in phase transitions between 4 and $5 \mathrm{GPa}$. This is in contrast to the behaviour of $\mathrm{Bi}_{2} \mathrm{~S}_{3}, \mathrm{Sb}_{2} \mathrm{~S}_{3}$ and, to some extent, $\mathrm{PbBi}_{2} \mathrm{~S}_{4}$ which also have been studied in detail in high pressure experiments (Lundegaard et al. 2003, 2005, Olsen et al. 2007). These three compounds have lone pairs which are "popped out" already at room pressure. The structures remain stable between 0 and $10 \mathrm{GPa}$ and the stereochemical activity of the lone pairs decreases as a function of increasing pressure.

The term piezoplastic phase transition was suggested for the transition in $\mathrm{Pb}_{3} \mathrm{Bi}_{2} \mathrm{~S}_{6}$ referring to its characteristics of being pressure induced, first-order, reversible, displacive, strongly anisotropic, and producing a major volume change (Olsen et al. 2008). It is evident from the description above that this term might apply equally well to the phase transition from heyrovskyite to $\beta-\mathrm{Pb}_{6} \mathrm{Bi}_{2} \mathrm{~S}_{9}$.

\section{Acknowledgement}

This work is a part of the EUOROCORES Programme EuroMinSci of the European Science Foundation (www.esf.org/eurominsci), through contract No. ERAS-CT-2003-980409 of the European Commission, DG Research, FP6. It is supported by the Danish Natural Science Research Council (272-08-0227 and 272-08-0233), the Spanish Ministerio de Ciencia y Innovación/ Ministerio de Educación y Ciencia (FIS2008-03834 and CGL2005-25095-E/BTE) and the Gobierno Vasco. Funding has also been received from the European Community's Seventh Framework Programme (FP7/2007-2013) under grant agreement number 226716. Portions of this research were carried out at the light source DORIS III at DESY. DESY is a member of the Helmholtz Association (HGF). We profited from the reviews by F. Laufek (Czech Geological Survey) and S. J. Mills (The University of British Columbia) and the editorial care of M. Rieder.

\section{References}

Altomare A, Burla MC, Camalli M, Cascarano GL, Giacovazzo C, Guagliardi A, Moliterni AGG, Polidori G, Spagna R (1999) SIR97: a new tool for crystal structure determination and refinement. J Appl Crystallogr 32:115-119

Angel RJ, Allan DR, Miletich R, Finger LW (1997) The Use of Quartz as an Internal Pressure Standard in High-Pressure Crystallography. J Appl Crystallogr 30:461-466

Angel RJ (2000) Equations of state. Rev Mineral Geochem 41:35-60

Angel RJ (2004) Absorption corrections for diamond-anvil pressure cells implemented in the software package - Absorb6.0. J Appl Crystallogr 37:486-492 
Balić-Žunić T, Makovicky E (1996) Determination of the centroid or 'the best centre' of a coordination polyhedron. Acta Crystallogr (B) 52:78-81

Berlepsch P, Makovicky E, Balić-Žunić T (2001a) Crystal chemistry of meneghinite homologues and related sulfosalts. N Jb Miner Mh 3:115-135

Berlepsch P, Makovicky E, Balić-Žunić T (2001b) Crystal chemistry of sartorite homologues and related sulfosalts. N Jb Miner Abh 176:45-66

Birch F (1947) Finite elastic strain of cubic crystals. Phys Rev 71:809-824

Boehler R (2006) New diamond cell for single-crystal x-ray diffraction. Rev Sci Instrum 77:115103-3

Elcoro L, Perez-Mato JM, Friese K, Petř́iček V, Balić-Žunić T, Olsen LA (2008) Modular crystals as modulated structures: the case of the lillianite homologous series. Acta Crystallogr (B) 64:684701

Hamilton WC (1965) Significance Tests on the Crystallographic $R$ Factor*. Acta Crystallogr $18: 502-510$

Kabsch W (1993) Automatic processing of rotation diffraction data from crystals of initially unknown symmetry and cell constants. J Appl Crystallogr 26:795-800

Klomínský J, Rieder M, Kieft C, Mráz L (1971) Heyrovskýite, 6(Pb0.86Bi0.08(Ag,Cu)0.04)S.Bi2S3 from Hůrky, Czechoslovakia, a New Mineral of Genetic Interest. Mineral. Deposita 6:133-147

Lundegaard LF, Miletich R, Balić-Žunić T, Makovicky E (2003) Equation of state and crystal structure of Sb2S3 between 0 and $10 \mathrm{GPa}$. Phys Chem Minerals 30:463-468

Lundegaard LF, Makovicky E, Boffa-Ballaran T, Balić-Žunić T (2005) Crystal structure and cation lone electron pair activity of Bi2S3 between 0 and $10 \mathrm{GPa}$. Phys Chem Minerals 32:578-584

Makovicky E, Karup-Møller S (1977) Chemistry and crystallography of the lillianite homologous series. N Jb Miner Abh 130:264-287

Makovicky E, Mumme WG (1983) The crystal-structure of ramdohrite, Pb6Sb11Ag3S24, and its implications for the andorite group and zinckenite. N Jb Miner Abh 147:58-79

Makovicky E, Mumme WG, Hoskins BF (1991) The crystal structure of Ag-Bi-bearing heyrovskyite. Can Mineral 29:553-559

Makovicky E (1993) Rod-based sulphosalt structures derived from the SnS and PbS archetypes. Eur J Mineral 5:545-591 
Mao HK, Xu J, Bell PM (1986) Calibration of the ruby pressure gauge to 800-kBar under quasihydrostatic conditions. J Geophys Res 91:4673-4684

Olsen LA, Balić-Žunić T, Makovicky E, Ullrich A, Miletich R (2007) Hydrostatic compression of galenobismutite $(\mathrm{PbBi} 2 \mathrm{~S} 4)$ : elastic properties and high-pressure crystal chemistry. Phys Chem Minerals 34:467-475

Olsen LA, Balić-Žunić T, Makovicky E (2008) High-Pressure Anisotropic Distortion of Pb3Bi2S6: a Pressure-Induced, Reversible Phase Transition with Migration of Chemical Bonds. Inorg Chem 47:6756-6762

Otto HH, Strunz H (1968) Zur Kristallchemie synthetischer Blei-Wismut Spiessglanze. N Jb Miner Abh 108:1-19

Petrríček V, Dusek M, Palatinus L (2006) Jana2006. Institute of Physics, Praha, Czech Republic STOE \& Cie GmbH, Darmstadt, Germany

Takéuchi Y, Takagi J (1974) The Structure of Heyrovskyite (6PbS·Bi2S3). Proc Japan Acad 50:7679

\section{Figure captions}

Fig. 1 One unit cell from the crystal structure of synthetic Ag-free heyrovskyite, $\mathrm{Pb}_{6} \mathrm{Bi}_{2} \mathrm{~S}_{9}$. Gray circles represent atoms on the $z=0$ mirror plane, white circles represent atoms on the $z=0.5$ mirror plane. $M 1$ and $M 3$ are considered as pure $\mathrm{Pb}$-sites and mixed occupation of $\mathrm{Pb}$ and $\mathrm{Bi}$ is assumed for $M 2, M 4$ and $M 5$. Cores of the lone electron pair micelles are indicated by ruling in the slab at the left side of the figure. The orientation of the PbS-archetype axes inside one (010) structural slab is indicated

Fig. 2 Evolution of unit-cell parameters of $\mathrm{Pb}_{6} \mathrm{Bi}_{2} \mathrm{~S}_{9}$ with increasing pressure. Squares indicate $a$, diamonds $b$, and circles $c$-axis. The dashed line represents half length of the $a$-axis

Fig. 3 Element specific bond-length hyperbola for pairs of opposing bonds in the octahedral coordination polyhedra of heyrovskyite. Bond-length hyperbola are from Berlepsch et al. (2001a). Numbers indicate the M-cation position

Fig. 4 One unit cell from the crystal structure of $\beta-\mathrm{Pb}_{6} \mathrm{Bi}_{2} \mathrm{~S}_{9}$ at $5.06 \mathrm{GPa}$. Gray circles represent atoms approx. on the $z=0.25$ plane, white circles represent atoms approx. on the $z=0.75$ plane. Bonds shorter than $3.5 \AA$ are indicated. Cores of the lone electron pair micelles are indicated by ruling in the central part of the figure

Fig. 5 Modular representation of the crystal structure of $\beta-\mathrm{Pb}_{6} \mathrm{Bi}_{2} \mathrm{~S}_{9}$. Rod type 1 is dotted and Rod type 2 is striped 
Fig. 6 The crystal structure of heyrovskyite (a) and $\beta-\mathrm{Pb}_{6} \mathrm{Bi}_{2} \mathrm{~S}_{9}(\mathrm{~b})$. The shaded blocks are rotated as rigid bodies and retained across the phase transition. The stippled lines in (b) indicate the relative orientation of blocks in the low pressure phase 
Table 1 Experimental data for $\mathrm{Pb}_{6} \mathrm{Bi}_{2} \mathrm{~S}_{9}$ crystal 1

\begin{tabular}{lll}
\hline$P(\mathrm{GPa})$ & 0.0001 & 5.06 \\
\hline$a$ axis $(\AA)$ & $13.719(4)$ & $25.302(7)$ \\
$b$ axis $(\AA)$ & $31.393(9)$ & $30.819(9)$ \\
$c$ axis $(\AA)$ & $4.1319(10)$ & $4.0640(13)$ \\
$\mathrm{UC}$ volume $\left(\AA^{3}\right)$ & $1779.5(1.4)$ & $3169.0(2.8)$ \\
$\mathrm{Z}$ & 4 & 8 \\
$\rho\left(\mathrm{g} / \mathrm{cm}^{3}\right)$ & 7.274 & 8.1551 \\
$\mu\left(\mathrm{mm}^{-1}\right)$ & 77.24 & 19.217 \\
& & \\
Radiation $(\AA)$ & 0.71073 & 0.4 \\
$\#$ measured reflections & 5336 & 10065 \\
$\#$ unique reflections & 756 & 2936 \\
$\#$ observed reflections & $a$ & 2250 \\
$R_{\text {int }}$ & 452 & 12.62 \\
Range of $h, k, l$ & 6.86 & $-38 \leq h \leq 38$ \\
& $-14 \leq h \leq 14$ & $-32 \leq k \leq 32$ \\
& $-30 \leq k \leq 34$ & $-6 \leq l \leq 6$ \\
$R$ (obs) & $-4 \leq l \leq 4$ & 8.17 \\
$R_{\mathrm{w}}($ obs $)$ & & 9.23 \\
GoF (obs) & 3.95 & 1.48 \\
$\#$ parameters refined & 3.97 & 216 \\
\hline Crition & \\
\hline
\end{tabular}

${ }^{a}$ Criterion for observed reflections is $\left|F_{\mathrm{o}}\right|>3 \sigma$

Table 2 Unit-cell parameters of Crystal 2 at different pressures

\begin{tabular}{ccccc}
\hline $\begin{array}{c}\text { pressure } \\
(\mathrm{GPa})\end{array}$ & $\begin{array}{c}a \text { axis } \\
(\AA)\end{array}$ & $\begin{array}{c}b \text { axis } \\
(\AA)\end{array}$ & $\begin{array}{c}c \text { axis } \\
(\AA)\end{array}$ & $\begin{array}{c}\text { UC volume } \\
\left(\AA^{3}\right)\end{array}$ \\
\hline 1.68 & $13.563(1)$ & $31.061(11)$ & $4.0968(4)$ & $1725.9(6)$ \\
2.95 & $13.467(1)$ & $30.848(11)$ & $4.0705(4)$ & $1691.9(7)$ \\
3.92 & $13.395(1)$ & $30.669(11)$ & $4.0523(4)$ & $1664.8(6)$ \\
4.84 & $25.367(3)$ & $30.929(13)$ & $4.0668(6)$ & $3190.7(1.5)$ \\
5.57 & $25.261(3)$ & $30.763(14)$ & $4.0605(6)$ & $3155.5(1.6)$ \\
\hline
\end{tabular}


Table 3 Atomic coordinates and $\mathrm{U}$ values for synthetic heyrovskyite (Crystal 1) at room pressure

\begin{tabular}{lllllllllll}
\hline Atom & $x$ & $y$ & $z$ & $U_{\text {iso }}$ & $U_{11}$ & $U_{22}$ & $U_{33}$ & $U_{12}$ & $U_{13}$ & $U_{23}$ \\
\hline M1 & $0.4213(2)$ & 0.25 & 0.0 & $0.044(1)$ & $0.0327(14)$ & $0.068(2)$ & $0.0303(17)$ & 0.0 & 0.0 & 0.0 \\
M2 & 0.0 & 0.0 & 0.5 & $0.0154(7)$ & $0.0157(11)$ & $0.0140(12)$ & $0.0164(13)$ & $0.0003(8)$ & 0.0 & 0.0 \\
M3 & $0.2286(1)$ & $0.05820(5)$ & 0.0 & $0.0183(5)$ & $0.0178(7)$ & $0.0188(8)$ & $0.0183(10)$ & $0.0015(6)$ & 0.0 & 0.0 \\
M4 & $0.1821(1)$ & $0.17492(5)$ & 0.5 & $0.0181(5)$ & $0.0215(8)$ & $0.0142(8)$ & $0.0184(10)$ & $-0.0004(6)$ & 0.0 & 0.0 \\
M5 & $0.4553(1)$ & $0.11904(5)$ & 0.5 & $0.0159(5)$ & $0.0157(8)$ & $0.0159(8)$ & $0.0161(10)$ & $-0.0006(6)$ & 0.0 & 0.0 \\
S1 & $0.0443(6)$ & $0.1956(3)$ & 0.0 & $0.015(2)$ & & & & & & \\
S2 & $0.0869(6)$ & $0.0860(3)$ & 0.5 & $0.019(2)$ & & & & & & \\
S3 & $0.2796(9)$ & 0.25 & 0.5 & $0.016(3)$ & & & & & & \\
S4 & $0.3249(7)$ & $0.1465(3)$ & 0.0 & $0.028(2)$ & & & & & & \\
S5 & $0.3623(7)$ & $0.0267(3)$ & 0.5 & $0.017(2)$ & & & & & & \\
\hline
\end{tabular}

Table 4 Bond-lengths in heyrovskyite

\begin{tabular}{|c|c|c|c|c|}
\hline Cation & Anion & $\begin{array}{c}\text { Ag-free } \\
\text { Present study }\end{array}$ & $\begin{array}{c}\text { Ag-poor } \\
\text { Takéuchi and Takagi } 1974\end{array}$ & $\begin{array}{c}\text { Ag-rich } \\
\text { Makovicky et al. } 1991\end{array}$ \\
\hline \multirow[t]{3}{*}{ M1 } & S $3 \times 2$ & $2.837(9)$ & $2.82(2)$ & $2.86(4)$ \\
\hline & S1 14 & $3.167(7)$ & $3.21(1)$ & $3.27(3)$ \\
\hline & $\mathrm{S} 4 \times 2$ & $3.508(10)$ & $3.43(2)$ & $3.21(3)$ \\
\hline \multirow[t]{2}{*}{ M2 } & S5 54 & $2.922(7)$ & $2.94(1)$ & $2.91(2)$ \\
\hline & $\mathrm{S} 2 \times 2$ & $2.951(9)$ & $2.93(2)$ & $2.87(4)$ \\
\hline \multirow[t]{4}{*}{ M3 } & S5 52 & $2.934(7)$ & $2.91(1)$ & $2.92(2)$ \\
\hline & S5 & $2.943(10)$ & $2.92(2)$ & $2.85(3)$ \\
\hline & $\mathrm{S} 2 \times 2$ & $2.968(6)$ & $2.99(1)$ & $2.90(2)$ \\
\hline & S4 & $3.071(10)$ & $3.09(2)$ & $3.06(3)$ \\
\hline \multirow[t]{4}{*}{ M4 } & S3 & $2.710(6)$ & $2.68(1)$ & $2.48(3)$ \\
\hline & $\mathrm{S} 1 \times 2$ & $2.875(6)$ & $2.84(1)$ & $2.76(3)$ \\
\hline & $\mathrm{S} 4 \times 2$ & $2.983(7)$ & $3.03(1)$ & $3.06(2)$ \\
\hline & S2 & $3.082(9)$ & $3.07(2)$ & $3.04(4)$ \\
\hline \multirow[t]{4}{*}{ M5 } & S1 & $2.696(9)$ & $2.66(2)$ & $2.54(4)$ \\
\hline & $\mathrm{S} 4 \times 2$ & $2.865(7)$ & $2.83(1)$ & $2.82(2)$ \\
\hline & $\mathrm{S} 2 \times 2$ & $2.933(6)$ & 2.91(1) & 2.97(3) \\
\hline & S5 & $3.167(10)$ & $3.19(2)$ & $3.22(3)$ \\
\hline
\end{tabular}


Table 5 Atomic coordinates and $\mathrm{U}$ values for synthetic $\beta-\mathrm{Pb}_{6} \mathrm{Bi}_{2} \mathrm{~S}_{9}($ Crystal 1$)$ at $5.06 \mathrm{GPa}$

\begin{tabular}{|c|c|c|c|c|c|c|c|c|c|c|}
\hline Atom & $x$ & $y$ & $z$ & $U_{i s o}$ & $U_{11}$ & $U_{22}$ & $U_{33}$ & $U_{12}$ & $U_{13}$ & $U_{23}$ \\
\hline M1a & $0.3366(1)$ & $0.2257(3)$ & $0.703(2)$ & $0.022(3)$ & $0.029(1)$ & $0.032(7)$ & $0.004(1)$ & $-0.002(2)$ & $-0.0003(12)$ & $-0.006(2)$ \\
\hline M1b & $0.1131(1)$ & $0.2426(2)$ & $0.238(2)$ & $0.037(3)$ & $0.031(1)$ & $0.066(8)$ & $0.014(1)$ & $-0.002(2)$ & $0.002(3)$ & $-0.012(5)$ \\
\hline $\mathrm{M} 2 \mathrm{a}$ & $0.1526(1)$ & $0.4798(3)$ & $0.253(2)$ & $0.028(3)$ & $0.034(2)$ & $0.040(8)$ & $0.012(1)$ & $-0.003(2)$ & $0.006(2)$ & $0.000(3)$ \\
\hline $\mathrm{M} 2 \mathrm{~b}$ & $0.3804(1)$ & $0.4652(3)$ & $0.731(2)$ & $0.036(3)$ & $0.031(2)$ & $0.055(9)$ & $0.020(1)$ & $0.007(2)$ & $0.006(2)$ & $0.023(5)$ \\
\hline M3a & $0.2001(1)$ & $0.0256(2)$ & $0.732(2)$ & $0.031(3)$ & $0.028(2)$ & $0.046(8)$ & $0.018(1)$ & $-0.004(2)$ & $-0.012(3)$ & $0.008(4)$ \\
\hline M3b & $0.2545(1)$ & $0.3992(3)$ & $0.716(2)$ & $0.030(3)$ & $0.032(2)$ & $0.046(8)$ & $0.010(1)$ & $0.002(2)$ & $0.003(2)$ & $0.003(3)$ \\
\hline M3c & $0.0005(1)$ & $0.4534(3)$ & $0.240(2)$ & $0.028(3)$ & $0.033(2)$ & $0.031(8)$ & $0.020(1)$ & $0.001(2)$ & $-0.001(3)$ & $-0.025(4)$ \\
\hline M3d & $0.0112(1)$ & $0.0591(2)$ & $0.228(2)$ & $0.034(3)$ & $0.037(2)$ & $0.045(8)$ & $0.020(1)$ & $-0.007(2)$ & $0.014(3)$ & $0.007(5)$ \\
\hline M4a & $0.2253(1)$ & $0.1431(2)$ & $0.237(2)$ & $0.035(3)$ & $0.032(2)$ & $0.057(9)$ & $0.017(1)$ & $0.001(2)$ & $-0.003(3)$ & $-0.016(5)$ \\
\hline M4b & $0.2426(1)$ & $0.3116(2)$ & $0.228(2)$ & $0.023(2)$ & $0.028(1)$ & $0.022(7)$ & $0.019(1)$ & $-0.003(2)$ & $-0.013(3)$ & $-0.001(4)$ \\
\hline M4c & $0.4463(1)$ & $0.1587(3)$ & $0.723(3)$ & $0.033(3)$ & $0.041(2)$ & $0.032(8)$ & $0.027(2)$ & $0.016(3)$ & $-0.007(3)$ & $-0.005(5)$ \\
\hline M4d & $0.4774(1)$ & $0.2826(2)$ & $0.741(2)$ & $0.032(3)$ & $0.024(1)$ & $0.058(8)$ & $0.015(1)$ & $-0.002(2)$ & $-0.006(3)$ & $-0.009(4)$ \\
\hline M5a & $0.3485(1)$ & $0.0695(3)$ & 0.25 & $0.029(3)$ & $0.027(1)$ & $0.045(8)$ & $0.016(1)$ & $-0.004(2)$ & $-0.008(2)$ & $0.007(4)$ \\
\hline M5b & $0.3960(1)$ & $0.3458(2)$ & $0.243(2)$ & $0.028(3)$ & $0.028(2)$ & $0.040(7)$ & $0.016(1)$ & $0.005(2)$ & $-0.005(3)$ & $0.002(4)$ \\
\hline M5c & $0.1002(1)$ & $0.3682(2)$ & $0.736(2)$ & $0.033(3)$ & $0.029(2)$ & $0.053(8)$ & $0.019(1)$ & $-0.004(2)$ & $0.003(3)$ & $-0.002(5)$ \\
\hline M5d & $0.0892(1)$ & $0.1230(2)$ & $0.737(2)$ & $0.026(2)$ & $0.035(2)$ & $0.027(7)$ & $0.016(1)$ & $0.002(2)$ & $-0.010(3)$ & $-0.004(4)$ \\
\hline S1a & $0.1644(7)$ & $0.182(1)$ & $0.745(9)$ & $0.016(4)$ & & & & & & \\
\hline $\mathrm{S} 1 \mathrm{~b}$ & $0.1744(7)$ & $0.302(2)$ & $0.739(11)$ & $0.020(4)$ & & & & & & \\
\hline S1c & $0.3606(6)$ & $0.145(1)$ & $0.263(7)$ & $0.011(5)$ & & & & & & \\
\hline S1d & $0.4243(6)$ & $0.242(1)$ & $0.191(5)$ & $0.008(4)$ & & & & & & \\
\hline $\mathrm{S} 2 \mathrm{a}$ & $0.1506(8)$ & $0.078(2)$ & $0.224(12)$ & $0.027(5)$ & & & & & & \\
\hline $\mathrm{S} 2 \mathrm{~b}$ & $0.1692(6)$ & $0.392(1)$ & $0.223(10)$ & $0.015(4)$ & & & & & & \\
\hline $\mathrm{S} 2 \mathrm{c}$ & $0.4280(6)$ & $0.074(1)$ & $0.765(6)$ & $0.008(4)$ & & & & & & \\
\hline S2d & $0.4486(7)$ & $0.402(2)$ & $0.707(9)$ & $0.021(6)$ & & & & & & \\
\hline S3a & $0.2599(9)$ & $0.228(2)$ & $0.223(13)$ & $0.034(6)$ & & & & & & \\
\hline $\mathrm{S} 3 \mathrm{~b}$ & $0.0467(6)$ & $0.280(1)$ & $0.765(6)$ & $0.011(5)$ & & & & & & \\
\hline $\mathrm{S} 4 \mathrm{a}$ & $0.2761(6)$ & $0.086(1)$ & $0.769(5)$ & $0.001(3)$ & & & & & & \\
\hline $\mathrm{S} 4 \mathrm{~b}$ & $0.3343(8)$ & $0.318(2)$ & $0.763(9)$ & $0.026(6)$ & & & & & & \\
\hline $\mathrm{S} 4 \mathrm{c}$ & $0.0199(7)$ & $0.368(1)$ & $0.254(9)$ & $0.017(5)$ & & & & & & \\
\hline $\mathrm{S} 4 \mathrm{~d}$ & $0.0412(6)$ & $0.171(1)$ & $0.222(9)$ & $0.011(4)$ & & & & & & \\
\hline $\mathrm{S} 5 \mathrm{a}$ & $0.2377(7)$ & $0.486(1)$ & $0.716(9)$ & $0.016(5)$ & & & & & & \\
\hline $\mathrm{S} 5 \mathrm{~b}$ & $0.3287(7)$ & $0.413(2)$ & $0.221(11)$ & $0.022(5)$ & & & & & & \\
\hline $\mathrm{S} 5 \mathrm{c}$ & $0.0818(7)$ & $0.462(2)$ & $0.698(6)$ & $0.013(5)$ & & & & & & \\
\hline S5d & $0.0581(8)$ & $0.0001(15)$ & $0.719(11)$ & $0.025(5)$ & & & & & & \\
\hline
\end{tabular}

The origin of the unit-cell was constrained by fixing the z-coordinate of M5a to 0.25 
Table 6 Bond lengths in synthetic $\beta-\mathrm{Pb}_{6} \mathrm{Bi}_{2} \mathrm{~S}_{9}$ (Crystal 1) at $5.06 \mathrm{GPa}$

\begin{tabular}{|c|c|c|c|c|c|c|c|c|c|c|c|}
\hline \multirow[t]{7}{*}{ M1a } & $\mathrm{S} 3 \mathrm{a}$ & $2.75(4)$ & M3a & $\mathrm{S} 4 \mathrm{a}$ & $2.68(3)$ & M4a & $\mathrm{S} 3 \mathrm{a}$ & $2.76(5)$ & M5a & S1c & $2.35(4)$ \\
\hline & $\mathrm{S} 4 \mathrm{~b}$ & $2.85(5)$ & & S5a & $2.80(3)$ & & $\mathrm{S} 2 \mathrm{a}$ & $2.77(4)$ & & $\mathrm{S} 4 \mathrm{a}$ & $2.73(2)$ \\
\hline & $\mathrm{S} 3 \mathrm{a}$ & $2.87(4)$ & & $\mathrm{S} 2 \mathrm{a}$ & $2.85(5)$ & & S1a & $2.80(3)$ & & $\mathrm{S} 2 \mathrm{c}$ & $2.82(2)$ \\
\hline & S1d & $3.02(2)$ & & S5a & $2.90(3)$ & & S1a & $2.84(3)$ & & $\mathrm{S} 4 \mathrm{a}$ & $2.84(2)$ \\
\hline & S1d & $3.08(2)$ & & $\mathrm{S} 2 \mathrm{a}$ & $2.90(5)$ & & $\mathrm{S} 4 \mathrm{a}$ & $2.90(3)$ & & $\mathrm{S} 2 \mathrm{c}$ & $2.90(2)$ \\
\hline & S1c & $3.12(4)$ & & $\mathrm{S} 5 \mathrm{~b}$ & $3.55(5)$ & & $\mathrm{S} 4 \mathrm{a}$ & $3.07(3)$ & & S5a & $3.38(3)$ \\
\hline & S1c & $3.43(3)$ & & S5d & $3.68(2)$ & & S1c & $3.43(2)$ & & S5c & $3.77(4)$ \\
\hline \multirow[t]{9}{*}{ M1b } & $\mathrm{S} 3 \mathrm{~b}$ & $2.80(3)$ & M3b & S5a & $2.70(4)$ & M4b & $\mathrm{S} 3 \mathrm{a}$ & $2.62(5)$ & M5b & $\mathrm{S} 4 \mathrm{~b}$ & $2.64(4)$ \\
\hline & S4d & $2.86(3)$ & & $\mathrm{S} 5 \mathrm{~b}$ & $2.78(4)$ & & S1b & $2.65(4)$ & & $\mathrm{S} 5 \mathrm{~b}$ & $2.68(4)$ \\
\hline & $\mathrm{S} 3 \mathrm{~b}$ & $2.96(3)$ & & $\mathrm{S} 5 \mathrm{~b}$ & $2.81(4)$ & & S1b & $2.72(4)$ & & $\mathrm{S} 4 \mathrm{~b}$ & $2.77(4)$ \\
\hline & S1a & $3.03(4)$ & & $\mathrm{S} 2 \mathrm{~b}$ & $2.95(3)$ & & $\mathrm{S} 4 \mathrm{~b}$ & $3.00(3)$ & & S2d & $2.89(4)$ \\
\hline & S1a & $3.06(4)$ & & $\mathrm{S} 2 \mathrm{~b}$ & $2.99(3)$ & & $\mathrm{S} 2 \mathrm{~b}$ & $3.11(3)$ & & S2d & $3.09(4)$ \\
\hline & S1b & $3.15(4)$ & & $\mathrm{S} 4 \mathrm{~b}$ & $3.23(4)$ & & $\mathrm{S} 4 \mathrm{~b}$ & $3.19(3)$ & & S1d & $3.27(4)$ \\
\hline & S1b & $3.15(4)$ & & S1b & $3.61(4)$ & & $\mathrm{S} 5 \mathrm{~b}$ & $3.80(4)$ & & S4d & $3.71(2)$ \\
\hline & $\mathrm{S} 3 \mathrm{a}$ & $3.74(2)$ & & & & & & & & & \\
\hline & & & M3c & $\mathrm{S} 4 \mathrm{c}$ & $2.68(4)$ & M4c & $\mathrm{S} 2 \mathrm{c}$ & $2.65(4)$ & M5c & $\mathrm{S} 2 \mathrm{~b}$ & $2.74(3)$ \\
\hline \multirow[t]{8}{*}{ M2a } & S5c & $2.61(2)$ & & $\mathrm{S} 5 \mathrm{c}$ & $2.79(2)$ & & $\mathrm{S} 4 \mathrm{c}$ & $2.79(3)$ & & $\mathrm{S} 1 \mathrm{~b}$ & $2.76(4)$ \\
\hline & $\mathrm{S} 2 \mathrm{~b}$ & $2.73(4)$ & & $\mathrm{S} 2 \mathrm{c}$ & $2.80(2)$ & & S1c & $2.89(2)$ & & $\mathrm{S} 2 \mathrm{~b}$ & $2.82(3)$ \\
\hline & $\mathrm{S} 5 \mathrm{a}$ & $2.86(3)$ & & $\mathrm{S} 2 \mathrm{c}$ & $2.94(2)$ & & $\mathrm{S} 4 \mathrm{c}$ & $2.97(3)$ & & $\mathrm{S} 4 \mathrm{c}$ & $2.82(3)$ \\
\hline & $\mathrm{S} 5 \mathrm{c}$ & $2.93(2)$ & & $\mathrm{S} 5 \mathrm{c}$ & $3.02(2)$ & & S1c & $3.11(2)$ & & S5c & $2.92(5)$ \\
\hline & S5a & $3.07(3)$ & & $\mathrm{S} 5 \mathrm{c}$ & $3.35(4)$ & & $\mathrm{S} 3 \mathrm{~b}$ & $3.17(3)$ & & $\mathrm{S} 4 \mathrm{c}$ & 2.93(3) \\
\hline & $\mathrm{S} 2 \mathrm{c}$ & $3.55(3)$ & & $\mathrm{S} 2 \mathrm{c}$ & $4.14(4)$ & & S1d & $3.25(4)$ & & $\mathrm{S} 3 \mathrm{~b}$ & $3.04(4)$ \\
\hline & $\mathrm{S} 4 \mathrm{a}$ & $3.74(3)$ & & & & & S1d & $3.41(4)$ & & & \\
\hline & & & M3d & S5d & $2.53(4)$ & & & & M5d & S1a & 2.64(3) \\
\hline \multirow[t]{7}{*}{ M2b } & $\mathrm{S} 2 \mathrm{~d}$ & $2.59(4)$ & & S2d & $2.78(3)$ & M4d & S1d & $2.59(3)$ & & S4d & $2.75(3)$ \\
\hline & S5d & $2.74(4)$ & & S2d & $2.90(3)$ & & $\mathrm{S} 3 \mathrm{~b}$ & $2.61(3)$ & & S4d & $2.83(3)$ \\
\hline & S5d & $2.81(4)$ & & S5d & $2.95(4)$ & & S1d & $2.89(3)$ & & $\mathrm{S} 2 \mathrm{a}$ & $2.88(4)$ \\
\hline & S5b & $2.88(4)$ & & S5d & $3.00(4)$ & & S4d & $2.91(3)$ & & $\mathrm{S} 2 \mathrm{a}$ & $2.95(4)$ \\
\hline & $\mathrm{S} 5 \mathrm{~b}$ & $2.94(4)$ & & S4d & $3.53(4)$ & & S4d & $3.02(3)$ & & S2d & $3.65(2)$ \\
\hline & $\mathrm{S} 2 \mathrm{a}$ & $3.55(4)$ & & $\mathrm{S} 2 \mathrm{a}$ & $3.57(2)$ & & S2d & $3.77(5)$ & & S5d & $3.87(5)$ \\
\hline & S5a & $3.67(2)$ & & & & & $\mathrm{S} 4 \mathrm{~b}$ & $3.78(3)$ & & & \\
\hline
\end{tabular}


Figure 1

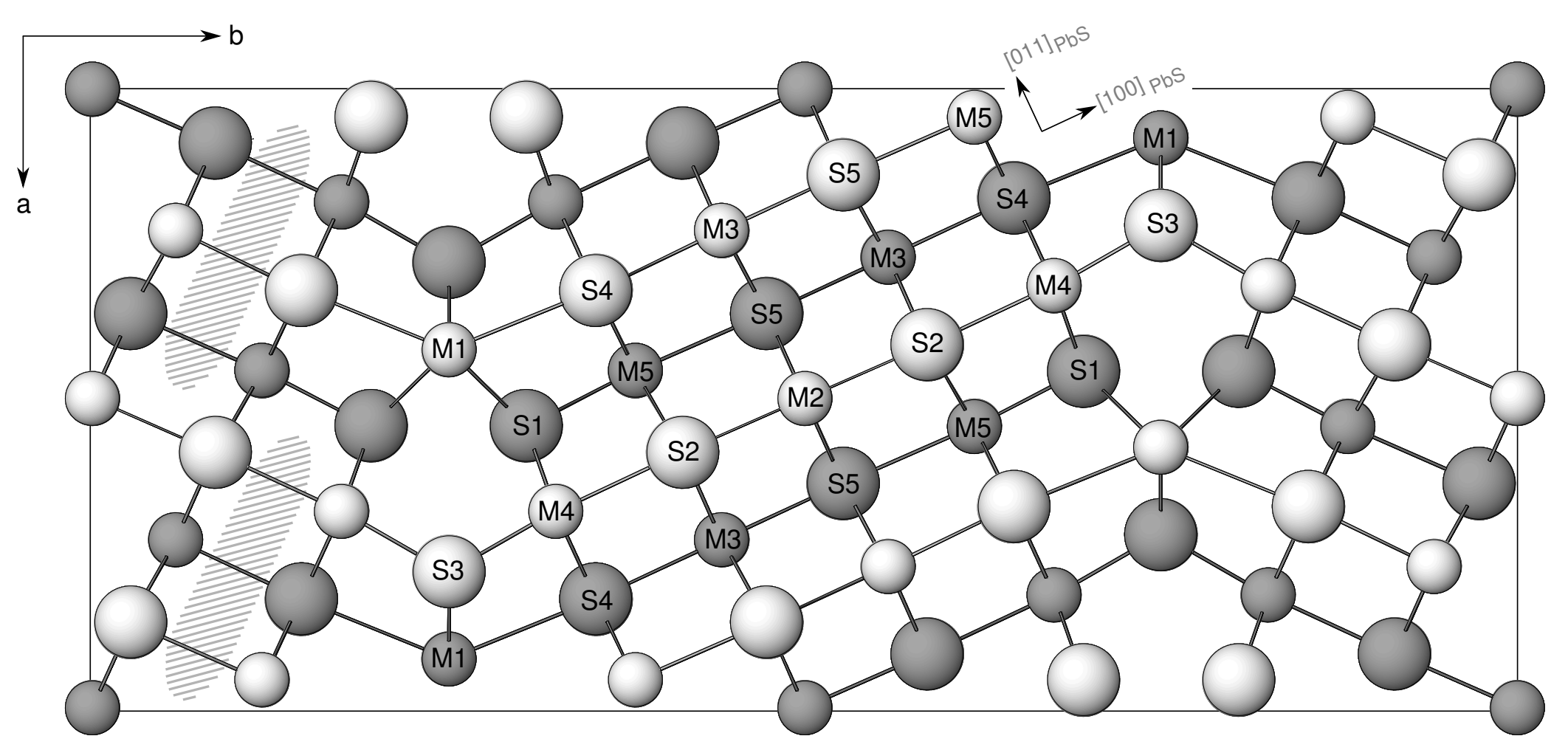




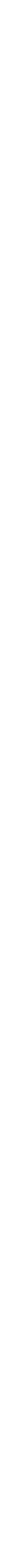

32

30

$\frac{8}{\frac{0}{4}}$

Pressure (GPa)

Figure 2 


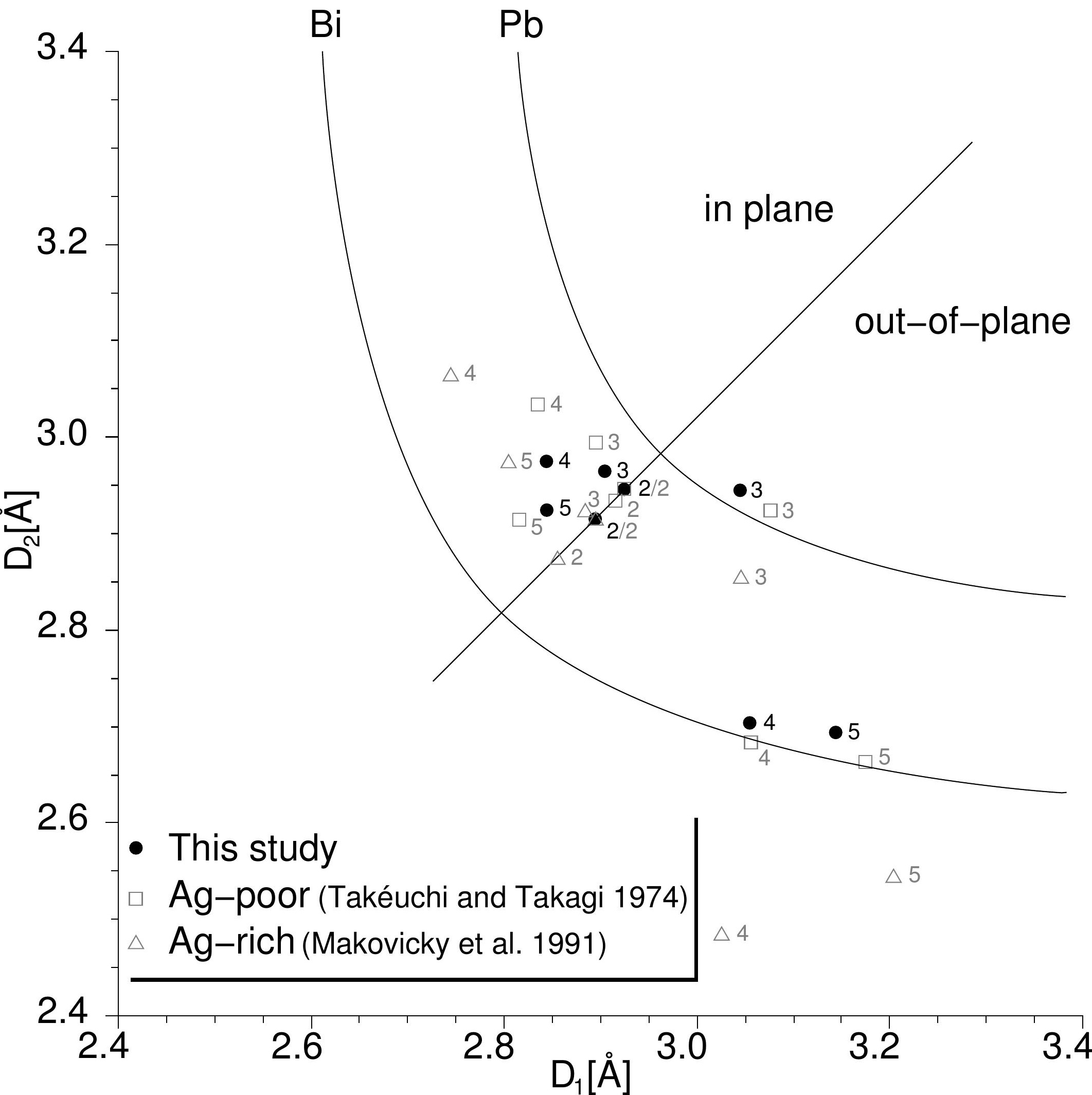


Figure 4

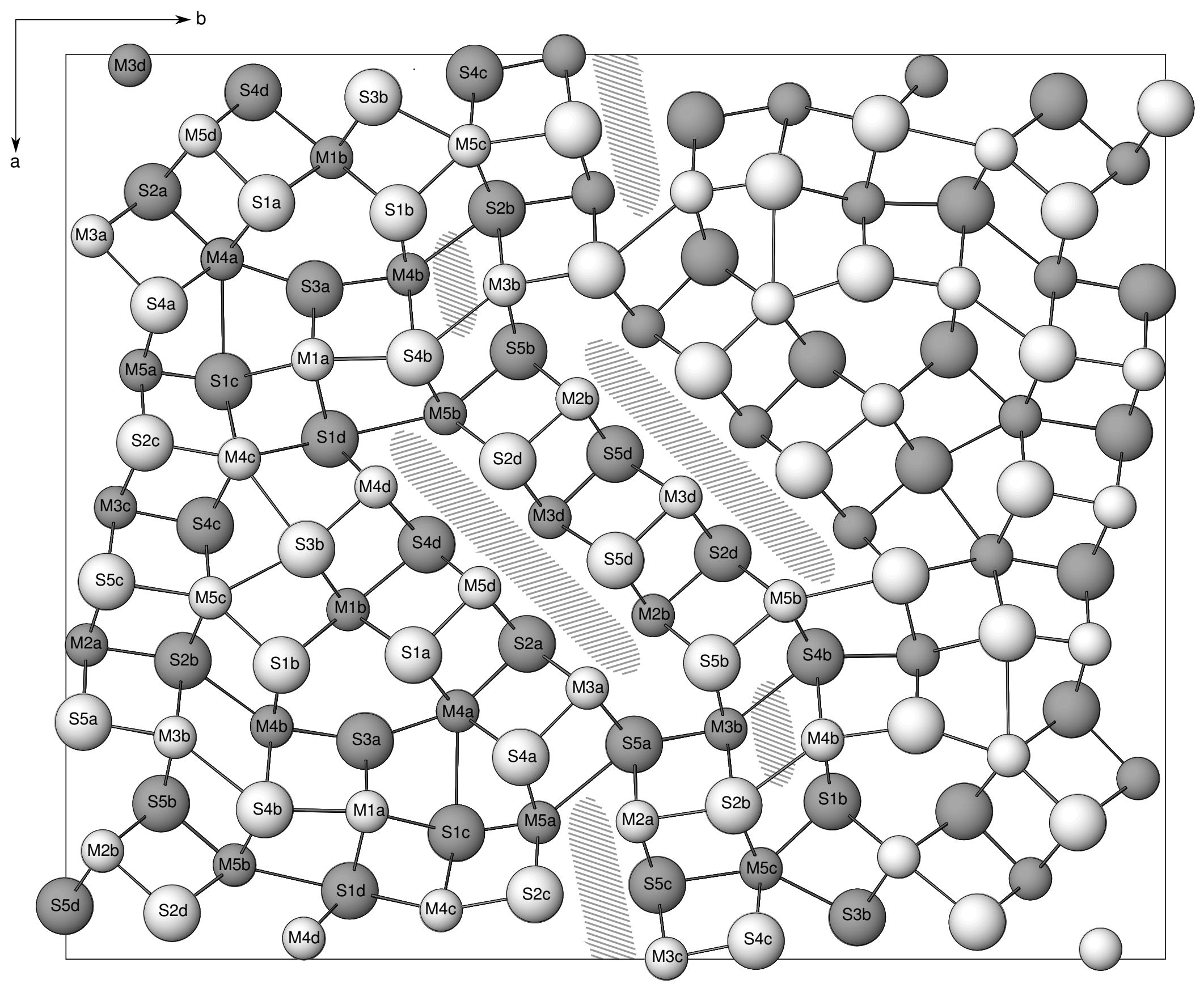




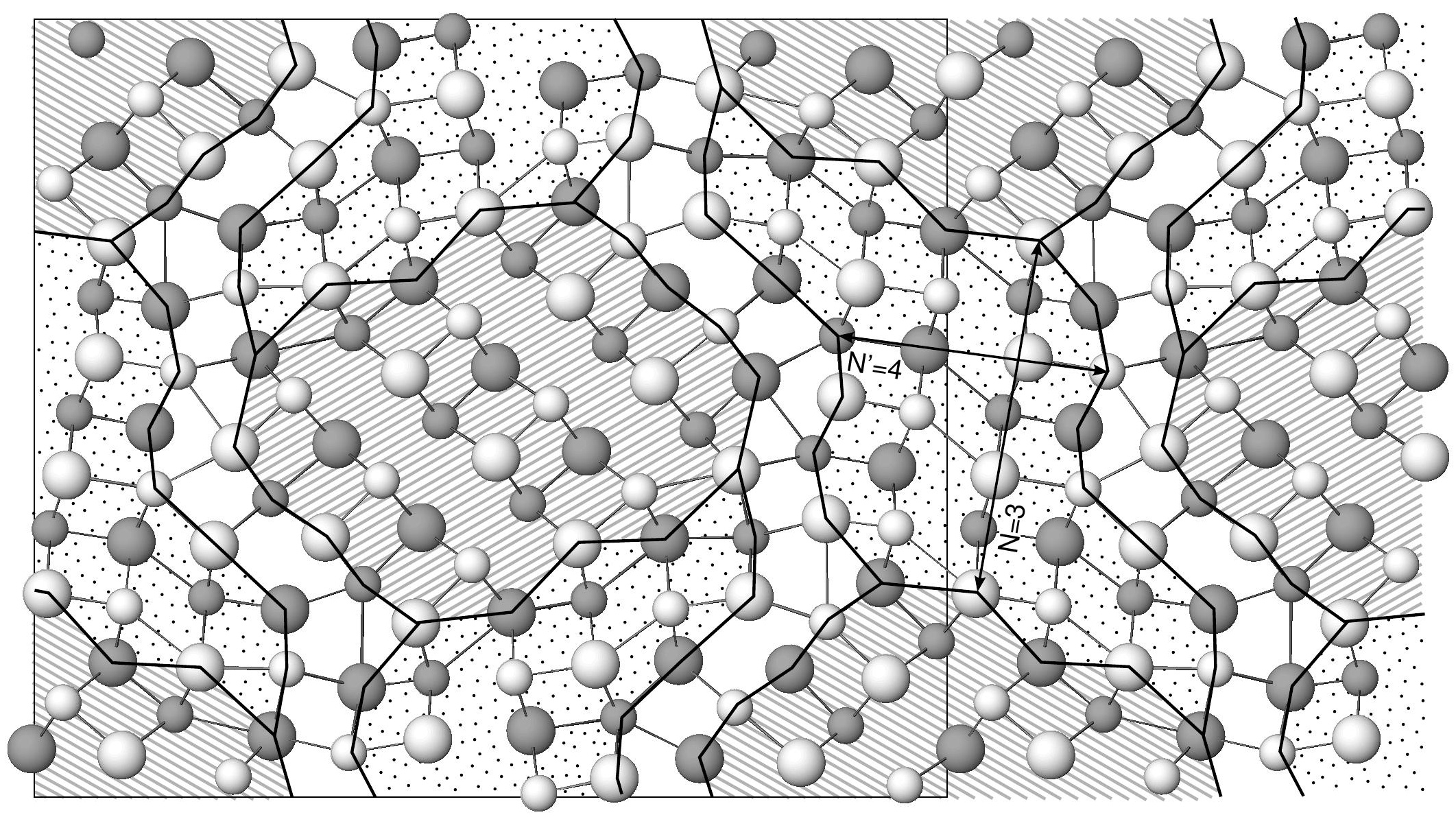




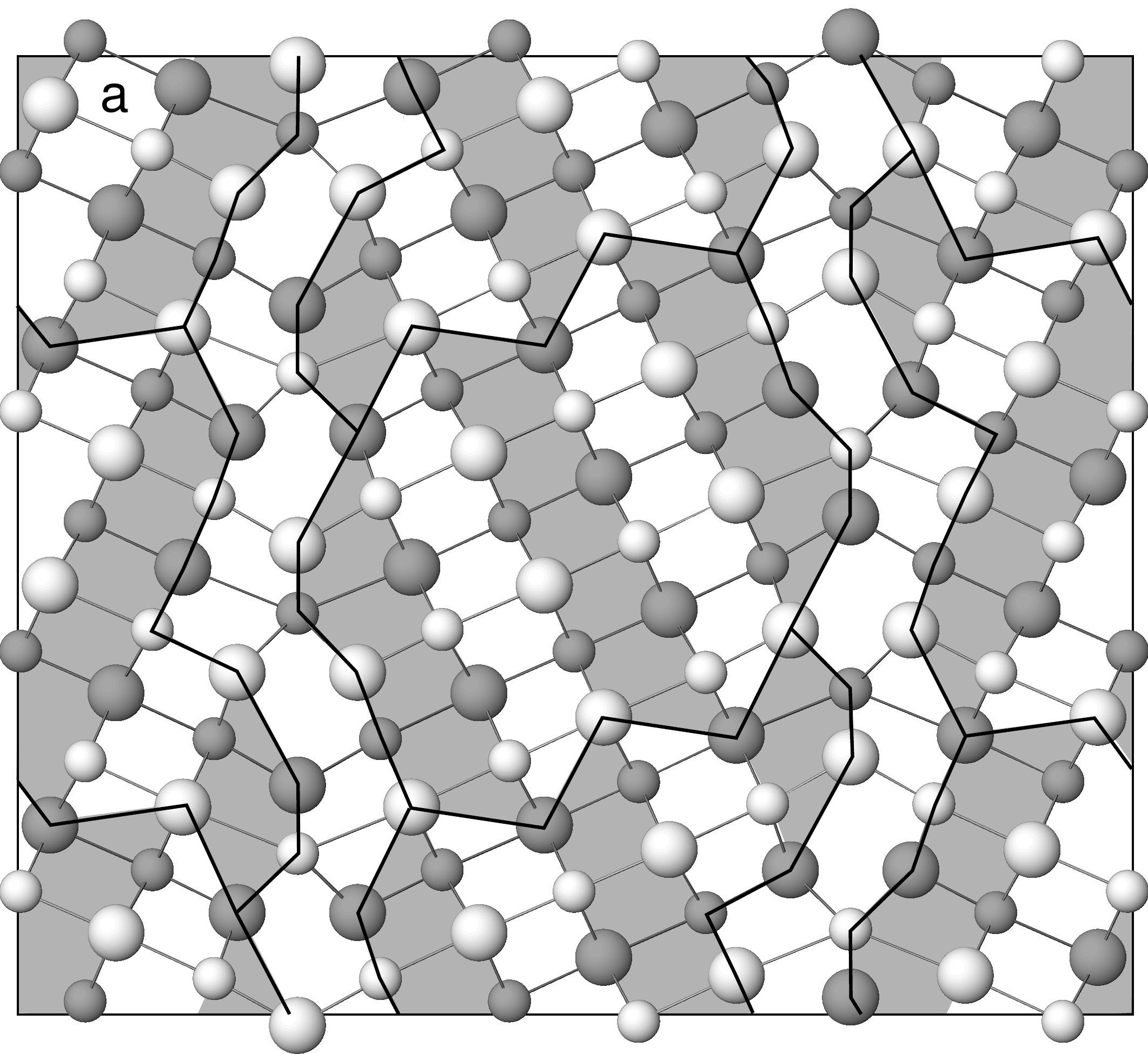




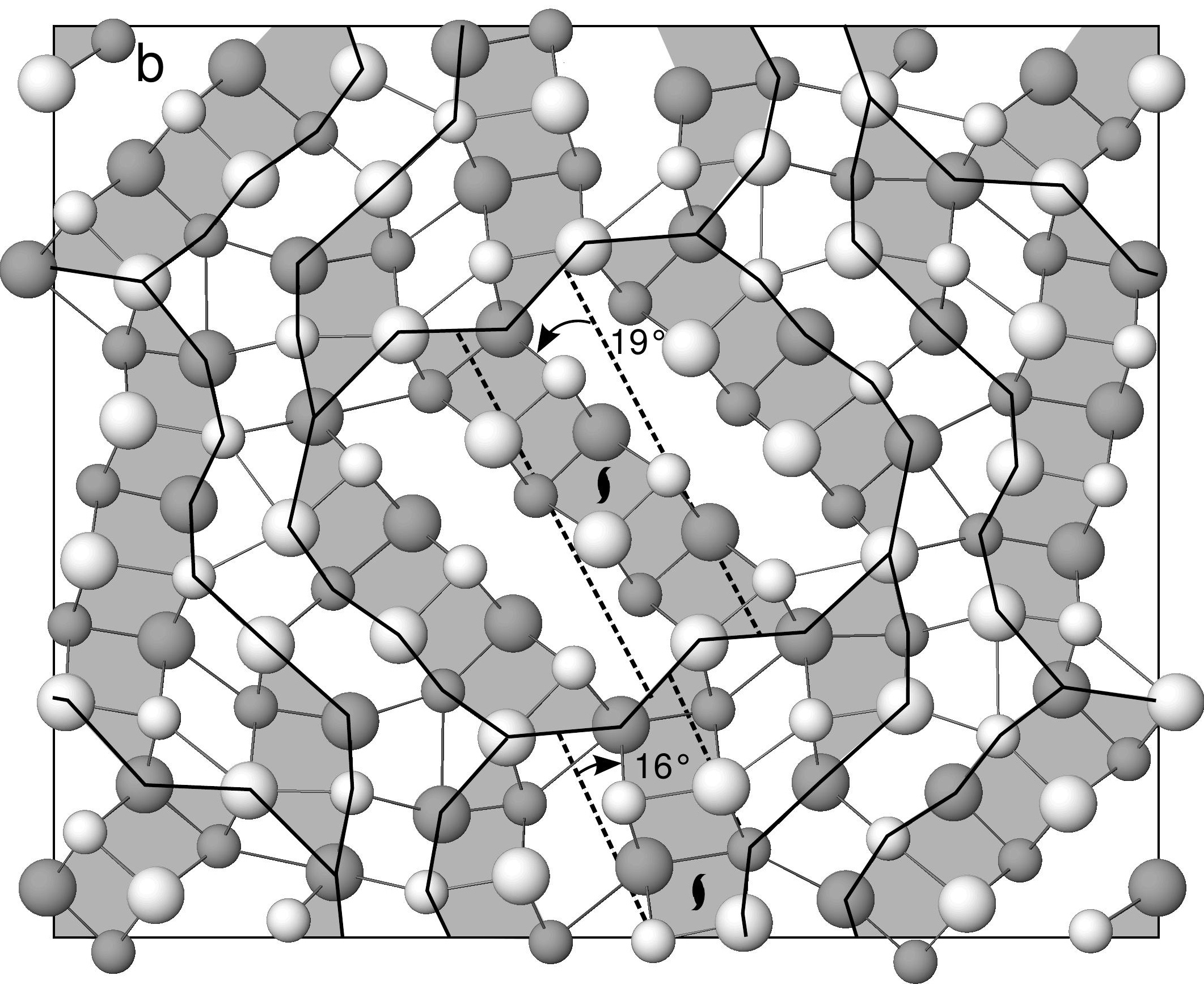

